Research article

Open Access

\title{
Functional interaction between mouse erbB3 and wild-type rat C-neu in transgenic mouse mammary tumor cells
}

\author{
Aeree Kim ${ }^{1,2 *}$, Bolin Liu ${ }^{1 *}$, Dalia Ordonez-Ercan ${ }^{1}$, Kathy M Alvarez ${ }^{1}$, Lynn D Jones ${ }^{1}$, \\ Christine McKimmey ${ }^{1}$, Susan M Edgerton ${ }^{1}$, XiaoHe Yang ${ }^{1}$ and Ann D Thor ${ }^{1}$
}

\author{
1Department of Pathology and College of Medicine, Oklahoma University Health Sciences Center (OUHSC), Oklahoma City, OK, USA \\ 2Department of Pathology, College of Medicine, Korea University, Seoul, Korea \\ * Contributed equally
}

Corresponding author: Ann D Thor, ann-thor@ouhsc.edu

Received: 7 Dec 2004 Revisions requested: 14 Feb 2005 Revisions received: 24 May 2005 Accepted: 10 Jun 2005 Published: 6 Jul 2005

Breast Cancer Research 2005, 7:R708-R718 (DOI 10.1186/bcr1281)

This article is online at: http://breast-cancer-research.com/content/7/5/R708

(c) Kim et al. licensee BioMed Central Ltd.

This is an Open Access article distributed under the terms of the Creative Commons Attribution License (http://creativecommons.org/licenses/by/

2.0,) which permits unrestricted use, distribution, and reproduction in any medium, provided the original work is properly cited.

\begin{abstract}
Introduction Co-expression of several receptor tyrosine kinases (RTKs), including erbB2 and erbB3, is frequently identified in breast cancers. A member of the RTK family, the kinase-deficient erbB3 can activate downstream signaling via heterodimer formation with erbB2. We studied the expression of RTK receptors in mammary tumors from the wild-type (wt) rat c-neu transgenic model. We hypothesized that physical and functional interactions between the wt rat neu/ErbB2 transgene and mouse ErbB3-encoded proteins could occur, activating downstream signaling and promoting mammary oncogenesis.
\end{abstract}

Methods Immunohistochemical and Western blot analyses were performed to study the expression of rat c-neu/ErbB2 and mouse erbB3 in mammary tumors and tumor-derived cell lines from the wt rat c-neu transgenic mice. Co-immunoprecipitation methods were employed to quantitate heterodimerization between the transgene-encoded protein erbB2 and the endogenous mouse erbB3. Tumor cell growth in response to growth factors, such as Heregulin (HRG), epidermal growth factor (EGF), or insulin-like growth factor-1 (IGF-1), was also studied. Post-HRG stimulation, activation of the RTK downstream signaling was determined by Western blot analyses using antibodies against phosphorylated Akt and mitogen-activated protein kinase (MAPK), respectively. Specific inhibitors were then used with cell proliferation assays to study the phosphoinositide-3 kinase (PI-3K)/Akt and MAPK kinase (MEK)/MAPK pathways as possible mechanisms of HRGinduced tumor cell proliferation.

Results Mammary tumors and tumor-derived cell lines frequently exhibited elevated co-expression of erbB2 and erbB3. The transgene-encoded protein erbB2 formed a stable heterodimer complex with endogenous mouse erbB3. HRG stimulation promoted physical and functional erbB2/erbB3 interactions and tumor cell growth, whereas no response to EGF or IGF-1 was observed. HRG treatment activated both the Akt and MAPK pathways in a dose- and time-dependent manner. Both the PI-3K inhibitor LY 294002 and MEK inhibitor PD 98059 significantly decreased the stimulatory effect of HRG on tumor cell proliferation.

Conclusion The co-expression of wt rat neu/ErbB2 transgene and mouse $E r b B 3$, with physical and functional interactions between these two species of RTK receptors, was demonstrated. These data strongly suggest a role for erbB3 in c-neu (ErbB2)-associated mammary tumorigenesis, as has been reported in human breast cancers.

\section{Introduction}

The erbB or epidermal growth factor receptor (EGFR) family forms subclass I of the receptor tyrosine kinase (RTK) super- family. Type I RTKs are expressed by epithelial, mesenchymal and neural tissues to regulate cell proliferation, differentiation and other important biological functions critical to species

DMEM = Dulbecco's modified Eagle's medium; EGF = epidermal growth factor; EGFR $=E$ EGF receptor; ER $=$ estrogen receptor; FBS $=$ fetal bovine serum; $\mathrm{HRG}=$ heregulin; IGF-1 = insulin-like growth factor-1; $\mathrm{mAb}=$ monoclonal antibody; MAPK = mitogen-activated protein kinase; MEK = MAPK kinase; MMTV = mouse mammary tumor virus; $\mathrm{PBS}=$ phosphate-buffered saline; RTK = receptor tyrosine kinase; $\mathrm{PI}-3 \mathrm{~K}=$ phosphoinositide 3-kinase; $\mathrm{RT}-\mathrm{PCR}=$ reverse transcription-polymerase chain reaction; SRB $=$ sulforhodamine $\mathrm{B} ; \mathrm{TCA}=$ trichloroacetic acid; TGF- $\alpha=$ transforming growth factor- $\alpha$. 
development [1]. Dysregulated expression of erbB receptors or mutational events thereof have been implicated in diverse types of human cancers $[1,2]$. Members of the family include: ErbB1 (also known as EGFR), ErbB2 (also known as Her-2 or neu), ErbB3 (or Her-3) and ErbB4 (or Her-4) [3-7]. erbB2 is an orphan receptor whereas other family members directly bind ligands (like the epidermal growth factor (EGF) and transforming growth factor- $\alpha$ (TGF- $\alpha$ ) for EGFR, and HRG for erbB3 and erbB4) to initiate intracellular signaling [8].

ErbB2 may be activated via either ligand-dependent heterodimeric, or ligand-independent homodimeric processes. In the former, erbB2 is the preferred heterodimerization partner for other erbB family receptors with bound ligand [9]. In ligandindependent signaling, erbB2 may be upregulated as a result of gene amplification, promoting homodimerization, or be activated through mutational events. ErbB2 amplification with enhanced protein expression is noted in approximately onethird of invasive human breast cancers [10]. Selected heterodimers may enhance receptor activation and downstream signaling as compared with homodimers $[1,11,12]$. Although erbB3 lacks a functional kinase to initiate cell signaling $[13,14]$, the erbB2/erbB3 heterodimer complex is believed to be the most biologically active and pro-tumorigenic form of these receptor complexes $[15,16]$.

The erbB receptors and their respective ligands influence a wide range of cellular processes such as proliferation, maturation, survival, apoptosis and angiogenesis [11,17-19]. In general, activated RTKs add phosphorylated tyrosine residues to downstream signaling molecules, such as the p85 subunit of phosphatidylinositol 3-kinase (PI-3K), Shc and/or Grb2 of the mitogen-activated protein kinase (MAPK) pathway. However, because of the complexity of RTK ligand-dependent and -independent mechanisms, the downstream signaling effects may be highly diverse and interactive. RTK-induced signaling is also influenced by, and may modulate, other molecular factors and signaling pathways.

The ErbB2 gene-encoded protein is over-expressed in 25 to $30 \%$ of invasive breast and ovarian cancers and has been associated with a poor clinical outcome [20-25].

Evidence of a causal relationship in human breast cancer has been derived from numerous prognostic studies and clinical trials. In vivo and in vitro model systems including transgenic mouse models support a relationship between erbB2 alterations and mammary tumorigenesis. Overexpression of erbB3 is also frequently reported in erbB2 altered breast, ovarian and bladder cancers $[23,26,27]$. Human breast cancer cell lines commonly co-overexpress both erbB2 and erbB3, further supporting their role in breast carcinogenesis $[2,11]$.

To investigate the role of RTKs in mammary tumorigenesis, transgenic mice bearing the wild-type (wt) or mutated, acti- vated rat c-neu (ErbB2) were generated, and have been widely studied [28-31]. Transgenic mice expressing the activated rat c-neu (with deletion mutations) bear mammary tumors with elevated co-expression of the mutant c-neul $E r b B 2$ and the endogenous mouse ErbB3-encoded protein [32]. Functional and physical interactions between these two cross-species receptors have not been reported, although interactions have been widely speculated. Transgenic mice bearing the wt-rat c-neu, under control of the mouse mammary tumor virus promoter (MMTV-LTR), typically develop unifocal, well-circumscribed, low-grade tumors after a long latency [29]. In addition to transgene expression and, in some cases, mutation, upregulation of EGFR and p53 have been reported in derived tumors $[33,34]$.

We have used the wt-erbB2 transgenic mouse model to study the effects of exogenous pharmacological or dietary estrogens and anti-estrogens. In particular, we have studied interactions between RTK-associated mammary tumorigenesis and steroid hormones. From the derived mouse tumors, we have established over 150 novel murine cell lines which have proven useful for in vitro studies $[35,36]$. Most tumor-derived cell lines express significant mouse ErbB3-encoded protein, in addition to high levels of the rat c-neu/ErbB2 transgene. These are also typically negative for $E R \alpha$ but show ER $\beta$ protein expression. A similar pattern of receptor expression has also been detected in the mouse mammary tumors.

The co-expression of erbB3 with erbB2 in both the activated and wt-neulErbB2 transgenic model systems suggested a biological role for erbB3 in mammary tumor pathogenesis. We hypothesized that physical and functional interactions between these RTK receptors should occur, despite their cross-species molecular structures. Signaling initiated by activated erbB2/erbB3 heterodimers should provide a more potent oncogenic signal than erbB2 homodimers alone. This would require ligand binding, most likely HRG, to activate erbB3. To test this hypothesis, we studied the responsiveness of tumor-derived cell lines to growth factors, including HRG, EGF and insulin-like growth factor-1 (IGF-1); we evaluated the effects of ligand stimulation and heterodimer formation on downstream signaling activation; and we sought evidence of physical interactions between the wt-rat c-neu/erbB2 and the endogenous mouse erbB3.

\section{Materials and methods \\ Cells and cell culture}

Human breast cancer cell lines SKBR-3 and BT-474 were obtained from the American Type Culture Collection (Rockville, MD, USA) and maintained in DMEM and Ham's F-12 medium (1:1, v/v) (Invitrogen Corp, Grand Island, NY, USA) supplemented with 10\% FBS (Invitrogen Corp). These cell lines were cultured in a $37^{\circ} \mathrm{C}$ humidified atmosphere containing $95 \%$ air and $5 \% \mathrm{CO}_{2}$ and were split twice a week. These human breast cancer cells were used primarily as controls. 


\section{Establishment of novel, mouse mammary tumor cell lines}

Mammary tumors were obtained from the transgenic mice by surgical removal immediately following euthanasia, according to our approved IACUC protocol. The histological pattern and tumor diagnoses were confirmed by microscopic analysis. These methods have been previously described in detail [35], although the specific cell lines described in this work have not been previously published. In brief, solid tumor tissue was transferred into a tissue culture dish containing PBS. After removal of mammary fat and connective tissues, tumors were minced into small pieces and treated with $0.25 \%$ trypsinEDTA (Invitrogen Corp) at $37^{\circ} \mathrm{C}$ for $30 \mathrm{~min}$. Cells were subsequently centrifuged at 1,200 rpm for $5 \mathrm{~min}$. After discarding supernatant, cells were suspended in DMEM/F12 medium supplemented with $10 \%$ FBS and $1 \%$ antibiotics and antimycotics (Invitrogen Corp). These mammary tumor cells $(\sim 1.0 \times$ $10^{6} \mathrm{cells} /$ plate) were seeded in tissue culture dishes and kept in a $37^{\circ} \mathrm{C}$ humidified atmosphere containing $95 \%$ air and $5 \%$ $\mathrm{CO}_{2}$. The media was changed twice a week to maintain cells in culture. Each line was passaged approximately 20 times before stability was assumed.

\section{Soft agar cloning assays}

Soft agar cloning was performed as described previously [35] with some modification. The bottom agar was prepared with a mixture of $1.6 \mathrm{ml}$ of $1 \times \mathrm{DMEM} / \mathrm{F} 12$ (complete medium), 3.2 $\mathrm{ml}$ of $2 \times \mathrm{DMEM} / \mathrm{F} 12$ (complete medium), and $3.2 \mathrm{ml}$ of $1.25 \%$ Noble agar (Sigma Co, St Louis, MO, USA) and maintained at $42^{\circ} \mathrm{C}$. From this, $2 \mathrm{ml}$ was pipetted into each well of six-well cell culture plates and agar was allowed harden in the hood. For each well, top agar was a mixture of $0.2 \mathrm{ml}$ of $1 \times$ DMEM/F12, $0.4 \mathrm{ml}$ of $2 \times \mathrm{DMEM} / \mathrm{F} 12$, and $0.4 \mathrm{ml}$ of $0.95 \%$ Noble agar. Five thousand cells (in $80 \mu$ l complete medium) were added into the top agar mixture. After vortexing gently, the cell containing top agar was added in a drop-wise fashion onto the bottom agar containing six-well plates (in triplicate per cell line). After resting for $10 \mathrm{~min}$ in the hood, the six-well plates were cultured in a $37^{\circ} \mathrm{C}$ incubator for 3 weeks. Colony counts were obtained under an inverted microscope, from three wells per cell line counting all colonies $>50 \mu \mathrm{M}$ in diameter.

\section{Doubling time in culture}

Measurement of cell growth rate in culture was determined using sulforhodamine B (SRB; Sigma Co) assays as previ- ously described [35]. Two thousand cells were seeded into each well of a six-well plate with complete medium. Cells were fixed with 50\% trichloroacetic acid (TCA) at $24 \mathrm{~h}$ intervals for 3 days. TCA-fixed cells were then stained with $0.4 \%$ SRB for $30 \mathrm{~min}$ followed by three washes. Protein-bound dye was dissolved in $10 \mathrm{mM}$ Tris base. Plates were read at $565 \mathrm{nM}$ using a micro-plate reader. Cell-doubling time was calculated based on proliferation curves that resulted from changes in SRB absorbance over time. Data represent the means of at least three independent experiments.

\section{Cell proliferation assay}

A CellTiter96 ${ }^{\text {TM }}$ AQ non-radioactive cell proliferation kit (Promega Corp, Madison, WI, USA) was used to determine the responsiveness of cells to various growth factors. Cells were plated onto 96-well plates, 5,000 cells/well for each cell line. Twenty-four hours later, the culture media were replaced by $0.5 \%$ FBS in DMEM/F12 fresh medium or the same medium containing $25 \mathrm{ng} / \mathrm{ml} \mathrm{HRG} \mathrm{(R \& D} \mathrm{Systems,} \mathrm{Inc,} \mathrm{Minne-}$ apolis, MN, USA), $10 \mathrm{ng} / \mathrm{ml}$ EGF (Sigma Chemical Co), or 40 $\mathrm{ng} / \mathrm{ml}$ IGF-1 (R\&D Systems, Inc) for another $72 \mathrm{~h}$ incubation with $5 \% \mathrm{CO}_{2}$ at $37^{\circ} \mathrm{C}$. After reading at $490 \mathrm{nM}$ with the microplate reader, the percentages of viable cells were determined by reduction of MTS (3-(4,5-dimethylthiazol-2-yl)-5-(3-carboxymethoxyphenyl)-2-(4-sulfophenyl)-2H-tetrazolium; inner salt) relative to controls. Data reflect the means of at least three independent experiments.

\section{RT-PCR and DNA sequencing analysis}

RT-PCR analyses were performed as previously described [37]. The primers specific for rat neu were synthesized according to the literature [38]. Forward primer AB2913, 5'CGG AAC CCA CAT CAG GCC-3' and reverse primer AB1310, 5'-TTT CCT GCA GCA GCC TAC GC-3' amplify the region corresponding to nucleotides 1492 to 2117 of rat neu cDNA [38]. The PCR products purified from agarose gel using QIAquick Gel Extraction Kit (Qiagen, Inc, San Valencia, CA, USA) were submitted to the core facility at the Oklahoma Medical Research Foundation for direct sequencing.

\section{Immunohistochemistry}

Immunohistochemical staining of mammary tumor tissues was performed as previously described [39]. Briefly, after deparaffinization and rehydration, tissue sections were steamed in a $10 \mathrm{mM}$ citrate buffer, $\mathrm{pH}$ 6.0, for $30 \mathrm{~min}$. Non-specific reactivity was blocked with $0.3 \% \mathrm{H}_{2} \mathrm{O}_{2}$ in buffer. For erbB3 immu-

\section{Table 1}

\begin{tabular}{llllll} 
Anchorage-independent cloning of mammary tumor-derived cell lines \\
\hline Cell Lines & SKBR-3a & 78423 & 78617 & 78717 & 83923 \\
Colonies in soft agarb & 422 & 87 & 49 & 24 & 85815 \\
\hline
\end{tabular}

aHuman breast cancer cell line SKBR-3 was used as positive control.

bColony numbers represent average of triplicates for each cell line. 
noassays, CAS Block (Zymed Laboratories, Inc, South San Francisco, CA, USA) and 10\% normal horse serum (Vector Laboratories, Inc, Burlingame, CA, USA) were used sequentially. For phospho-Akt immunostaining, we used $1 \% \mathrm{H}_{2} \mathrm{O}_{2}$ and $5 \%$ normal goat serum (Vector Laboratories, Inc) sequentially. Primary antibodies included an anti-erbB2 (reactive with rat c-neu/erbB2 rabbit polyclonal, dilution 1:1000 (Dako, Carpinteria, CA, USA) for $2 \mathrm{~h}$ incubation at room temperature), anti-erbB3 (cross-reacts with mouse and human, mouse monoclonal, dilution 1:50 (NeoMarkers, Inc, Fremont, CA, USA), overnight incubation at $4^{\circ} \mathrm{C}$ ), anti-phospho-Akt (rabbit polyclonal, diluted in 5\% normal goat serum 1:12.5 (Cell Signaling Technology, Beverly, MA, USA), overnight at $4^{\circ} \mathrm{C}$ ), or antiphospho-MAPK (E10 monoclonal antibody, diluted in 5\% normal goat serum 1:25 (Cell Signaling Technology), overnight at $\left.4^{\circ} \mathrm{C}\right)$. After multiple washes with buffer, tissue sections were sequentially incubated for $30 \mathrm{~min}$ at room temperature with diluted biotinylated secondary antibody (1:500; Dako) and VECTASTAIN Elite ABC reagent (Vector Laboratories, Inc) diluted in PBS. After reaction with diaminobenzidine (Dako) and counterstaining with hematoxylin, tumors were individually examined. Each slide was evaluated in its entirety for antigen expression, cell type and histopathological diagnoses.

\section{Immunoprecipitation and Western blot analysis}

Immunoprecipitation and Western blot assays were performed as previously described [40]. Briefly, cells were lysed in NP-40 lysis buffer ( $50 \mathrm{mM}$ Tris- $\mathrm{HCl}, \mathrm{pH} 7.4,150 \mathrm{mM} \mathrm{NaCl}$, $0.5 \% \mathrm{NP}-40,50 \mathrm{mM} \mathrm{NaF}, 1 \mathrm{mM} \mathrm{Na} \mathrm{VO}_{4}, 1$ mM phenylmethylsulfonyl fluoride, $25 \mu \mathrm{g} / \mathrm{ml}$ leupeptin, $25 \mu \mathrm{g} / \mathrm{ml}$ aprotinin). The supernatants were cleared by centrifugation. Protein concentrations were measured using the Coomassie plus protein assay reagent (Pierce Chemical Co, Rockford, IL, USA). Total cell lysates containing $200 \mu \mathrm{g}$ of protein were subjected to immunoprecipitation in the presence of $1 \mu \mathrm{g}$ anti-erbB2 antibody (mouse monoclonal antibody, Ab-4; Oncogene Science Products, Cambridge, MA, USA) for $2 \mathrm{~h}$ at $4^{\circ} \mathrm{C}$, followed by incubation with immobilized protein A-agarose (Roche Diagnostics Corp, Indianapolis, IN, USA) at $4^{\circ} \mathrm{C}$ overnight with rotation. For Western blot analyses, the immunoprecipitates or equal amounts of crude extracts were boiled in Laemmli SDSsample buffer, resolved by SDS-polyacrylamide gel electrophoresis, transferred to nitrocellulose (Bio-Rad Laboratories, Hercules, CA, USA), and probed with different primary antibodies. After the blots were incubated for another $1 \mathrm{~h}$ at room temperature with horseradish peroxidase-labeled secondary antibody (goat anti-rabbit lgG or goat anti-mouse lgG; Perkin Elmer, Boston, MA, USA), the signals were detected using the Enhanced Chemiluminance assay (Amersham Life Science Inc., Arlington Heights, IL, USA) according to the manufacturer's instructions.
Figure 1

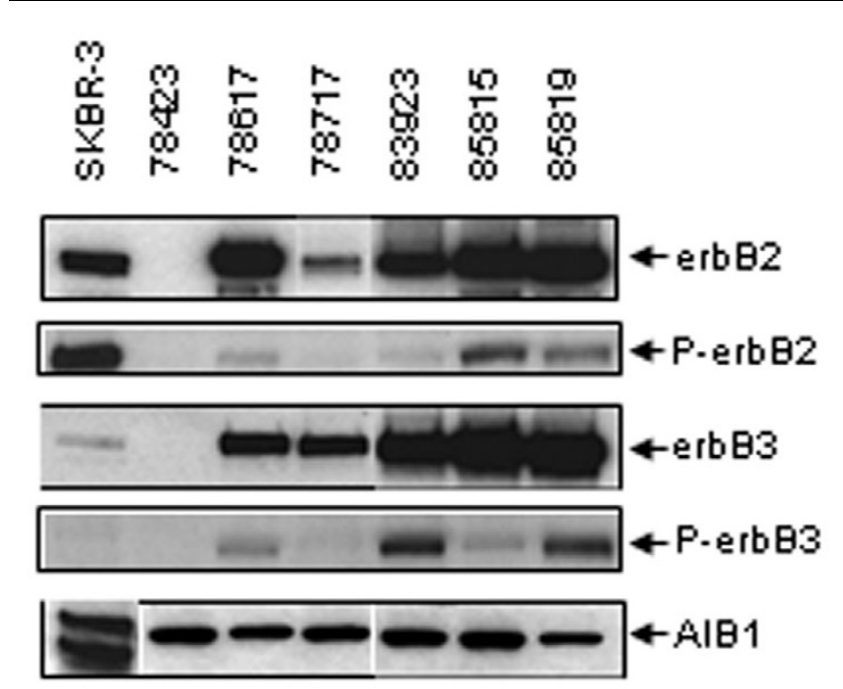

Protein expression of erbB2, P-erbB2, erbB3, P-erbB3 and AIB1 in breast tumor cell lines. The cell lysates from human breast cancer cell line SKBR-3 and the six novel, mammary tumor-derived cell lines were prepared as described in Materials and methods. $50 \mu \mathrm{g}$ total cell lysates were used for Western blot analyses with antibodies directed against erbB2 (c-neu Ab-3, Oncogene Research Products), P-erbB2 (clone PN2A, NeoMarkers, Inc), erbB3 (Ab-7, NeoMarkers, Inc), PerbB3 (clone 21D3, Cell Signaling Technology) and AIB1 (clone 34, BD Biosciences Pharmingen, San Diego, CA, USA).

\section{Results \\ Co-expression of erbB2 and erbB3 protein in tumor- derived cell lines and tumors}

Western blot analyses were used to determine erbB2 and erbB3 protein expression in tumor-derived cell lines (and the control SKBR-3 human breast cancer cell line). The majority of tumor-derived cell lines expressed moderate to high levels of both erbB3 and erbB2 (Fig. 1). In general, lines with the highest erbB2 expression showed the highest levels of erbB3 protein. Tyrosine phosphorylation (activation) of these receptors was examined by Western blots using antibodies specific for phophorylated erbB2 (P-erbB2) or phosphorylated erbB3 (PerbB3). Tumor lines with co-overexpression of both proteins showed higher P-erbB2 and P-erbB3 levels (Fig. 1). The intensity of P-erbB2 and P-erbB3 signals did not necessarily correlate with their corresponding protein levels. The expression of either receptor protein was undetectable in only one of our novel, derived tumor cell lines (78423). AlB-1 (also called SRC3, RAC3, ACTR and p/CIP), a co-activator of estrogen receptor commonly amplified in breast cancer cells [41], was used as a loading control. Expression of AIB-1 further established the origin of these cells as mammary-derived.

To confirm the transformed characteristics of these lines, soft agar cloning assays (which quantitate anchorage-independent cloning capability) were used. All six tumor-derived cell lines formed colonies in soft agar. Colony formation was variable 
Figure 2
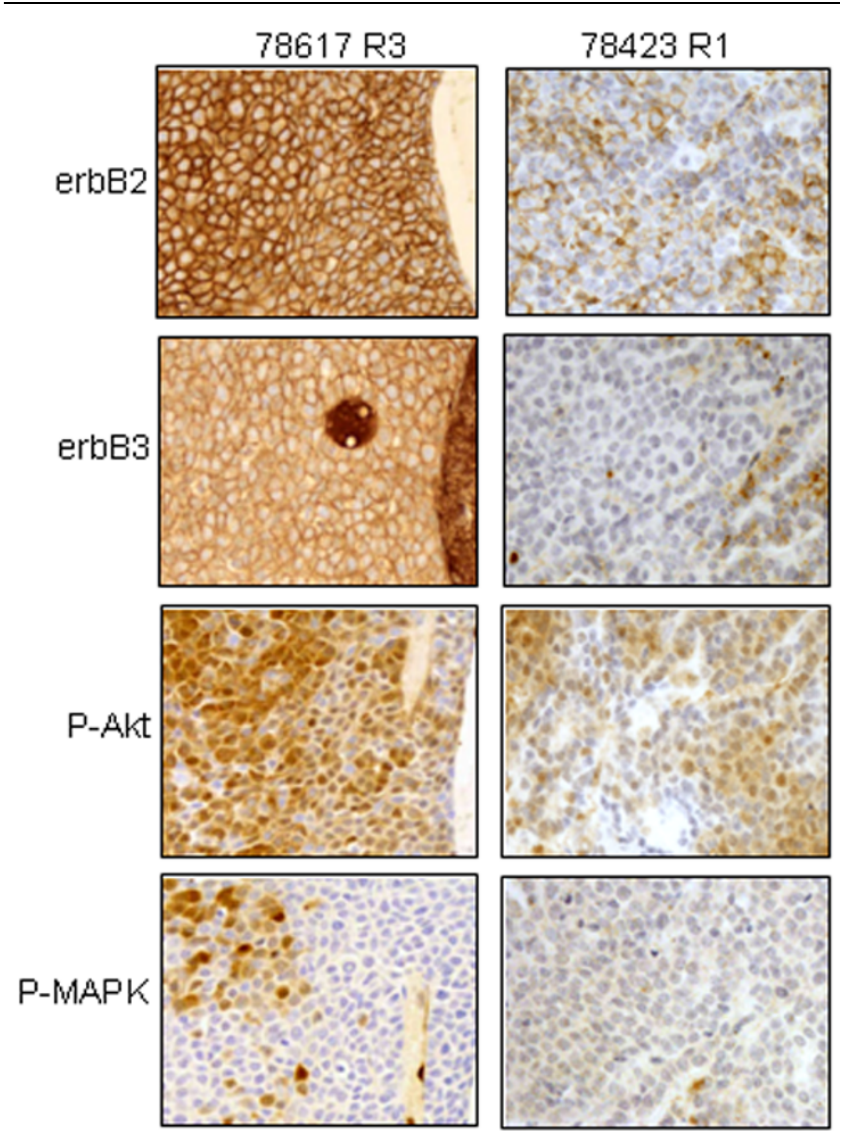

Immunohistochemical staining for erbB2, erbB3, phospho-Akt (P-Akt) and phospho-MAPK (P-MAPK) in mammary tumor tissues. Representative photomicrographs were taken from the similar area of 78617 R3 and $78423 \mathrm{R} 1$ mammary tumor sections (40X).

when comparing one cell line with another (range 17-180, Table 1). There was no correlation between the ability of a cell line to form anchorage-independent clones and the expression levels of erbB2 or erbB3.

Immunohistochemical methods were used to visualize RTK expression and downstream signaling (protein activation) by tumors in situ. Tumors showed strong and typically diffuse coexpression of both erbB2 and erbB3. The only exception to this was the mammary tumor $78423 \mathrm{R} 1$, the progenitor of the cell line that did not co-express erbB2 and erbB3 discussed above. We also studied RTK signaling activation in situ, using phosphospecific antibodies. Phosphorylated-Akt (P-Akt) showed cytoplasmic and membranous staining, which was less diffuse than the erbB-2 expression. PhosphorylatedMAPK (P-MAPK) was the most selectively expressed, typically expressed by clustered or isolated tumor cells as shown in Fig. 2 (left panel) with tumor 78617 R3. The majority of tumor cells from 78423 R1 were erbB3 negative, although some cells showed weak erbB2 protein expression. In this later tumor, $\mathrm{P}$ Akt staining was weak with clustered or isolated tumor cells and no staining for P-MAPK was observed (Fig. 2, right panel). The histological, cytological and biological features of these tumors have been reported elsewhere [36,42]. As a control, we also studied cytokeratin expression and all tumors were positive. This confirmed the epithelial nature of these tumors (data not shown).

\section{Sequencing analyses of the transgene neu in established mammary tumor-derived cell lines}

As alluded to above, in-frame deletions of 7-12 amino acids have been reported in the extracellular region of the transgene, proximal to the transmembrane domain [38]. To study the mutational status of tumor-derived lines, we performed RTPCR amplification of exactly the same region followed by direct sequencing analysis. The PCR primers used were specific for rat neu and were designed to amplify the 603 bp extracellular region [38]. Of six tumor-derived cell lines used in this manuscript and therefore studied for mutation, only four showed PCR gene amplification (Fig. 3a). Of these, the strongest PCR signal was seen in 85819 cells. These data are consistent with our Western blot results that showed overexpression of the rat neu/erbB2 in only the four PCR-positive lines (Fig. 1). Direct sequencing of the PCR products revealed no deletion mutations in the amplified product. Sequencing showed three of the four were wt rat neu cDNA sequence. Sequencing data from the 83923 cells indicated a mixture of two kinds of neu cDNA. Using a reverse primer, we verified that both wt and point mutation neu transcripts co-existed in 83923 cells (Fig. 3 b). This suggests biclonal populations or a heterozygous mutation. Further studies and sub-cloning are in process.

\section{Mammary tumor cell response to growth factors corresponds with erbB receptor data}

To study the functionality and interactions of the erbB receptors, 78423 and other three representative mouse mammary tumor-derived lines with the highest expression of wt erbB2 and co-expression of erbB3 were chosen for further study. Baseline proliferation was determined using monolayer culture conditions and the SRB assay (Fig. 4a). Some variability in the basal doubling time was observed between these cell lines. The mouse mammary tumor cell lines 78423, 78617, 85815 and 85819 showed population doubling times of $15.15 \pm$ $1.10,16.25 \pm 1.40,30.85 \pm 2.31$ and $20.35 \pm 1.89 \mathrm{~h}$, respectively. Using an MTS assay, we then tested the response of these lines to EGF, HRG and insulin-like growth factor (IGF)-1 (Fig. 4b). HRG strongly stimulated the proliferation of three of the four mouse mammary tumor cell lines (78617, 85815, 85819) with overexpression of both erbB2 and erbB3. Proliferation was not induced by EGF or IGF-1, which bind to EGFR and IGF-1 receptor, respectively. HRG also promoted the growth of SKBR-3 and BT-474 human breast cancer cells (controls). These data strongly support a functional interaction between the wt-rat neu/ErbB2 and endogenous mouse erbB3. 
Figure 3

(a)

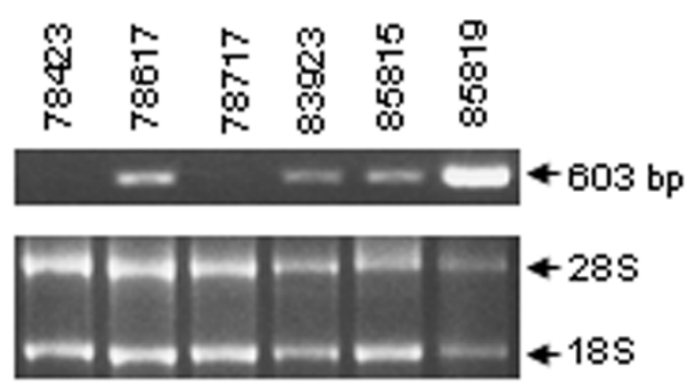

(b)

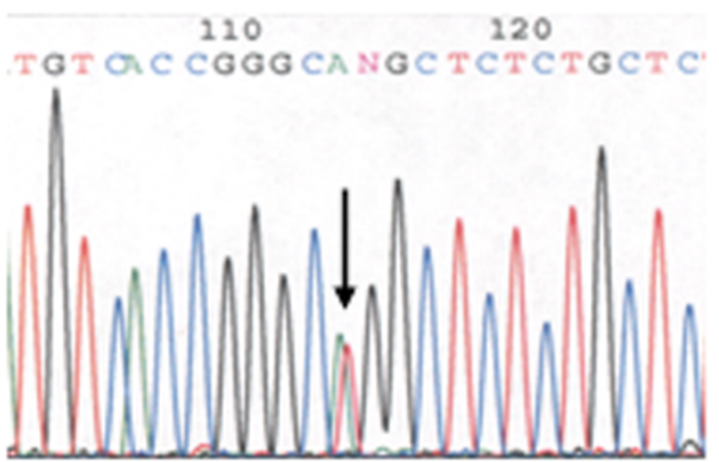

RT-PCR and sequencing analyses of partial extracellular domain of rat $n e u$ in the tumor-derived cell lines. (a) RT-PCR analyses of rat neu. Total RNA isolated from the indicated tumor cells by the TRIZOL reagent was analyzed with electrophoresis using a $1 \%$ agarose gel containing ethidium bromide and visualized under UV light (bottom). Firststrand cDNA was synthesized using a kit from Roche Diagnostics Corp. The partial extracellular domain of rat neu was amplified with specific primers. The PCR products were separated on a $1.2 \%$ agarose gel containing ethidium bromide and visualized under UV light (top). (b) Partial sequencing of the PCR product from 83923 cells with reverse primer AB1310. The mixture of wt nucleotide $T$ (red) and mutant nucleotide $\mathrm{A}$ (green) is indicated by an arrow.

\section{HRG activation of PI-3K/Akt and MAPK kinase (MEK)/} MAPK signaling promotes mammary tumor cell growth It is well documented that the MEK/MAPK and PI-3K/Akt pathways are the two major signal transduction pathways downstream of the erbB receptors [11,17-19]. To determine which signaling pathways were activated in the mouse-derived mammary tumor cells exposed to HRG, we performed Western blots to detect P-MAPK or P-Akt. With 2 h of HRG treatment, both P-Akt and P-MAPK increased in the 85815 and 85819 mouse mammary tumor cell lines (Fig. 5a). This study included a series of HRG concentrations, and stimulation was maximal
Figure 4
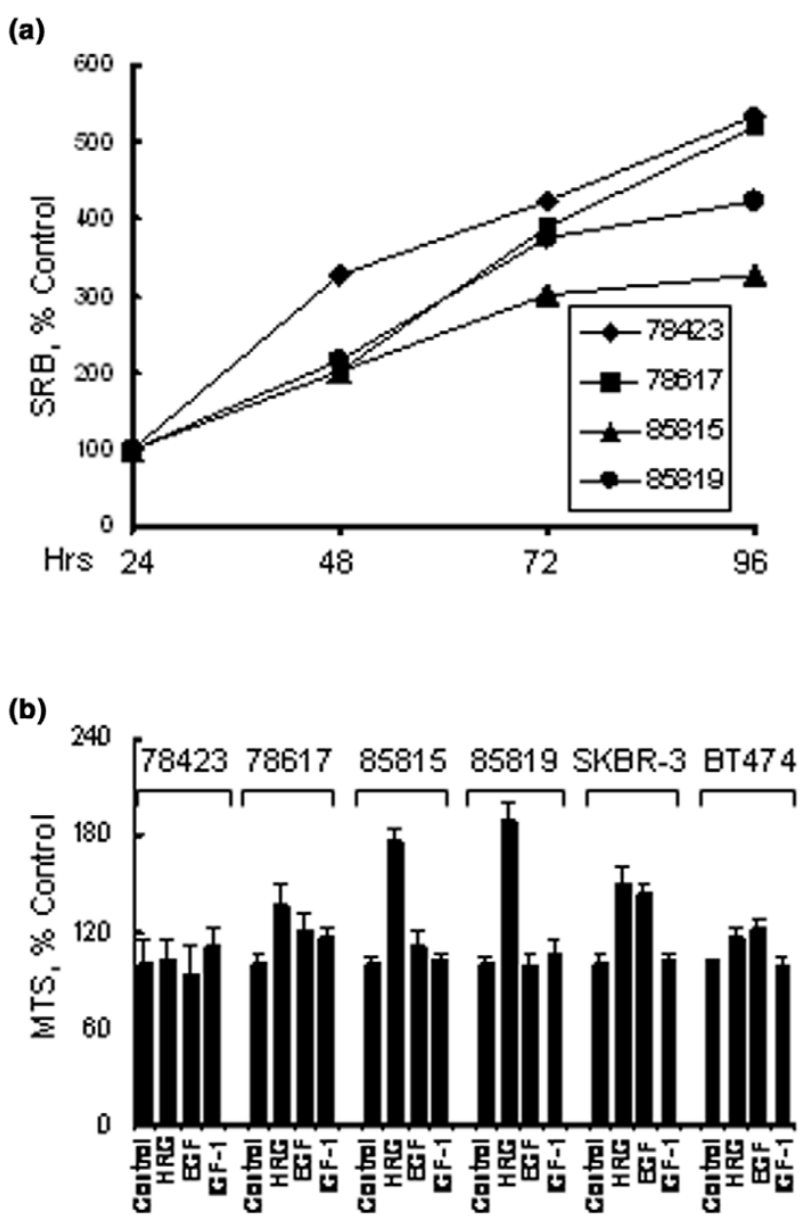

Proliferation of the tumor-derived cell lines and their responsiveness to growth factors. (a) The tumor-derived cell lines 78423, 78617, 85815 and 85819 were subjected to SRB assays for measurement of cell growth rate as described in Materials and methods. The means of at least three independent experiments were plotted. SD for each point was less than $10 \%$. (b) The indicated breast cancer cells $\left(5 \times 10^{3}\right)$ in $0.1 \mathrm{ml}$ culture media were plated onto 96 -well plates. After $24 \mathrm{~h}$ incubation, cells were grown in either $0.1 \mathrm{ml}$ fresh medium with $0.5 \%$ FBS as control, or $0.1 \mathrm{ml}$ same medium containing either $25 \mathrm{ng} / \mathrm{ml} \mathrm{HRG}$ or $10 \mathrm{ng} / \mathrm{ml} \mathrm{EGF}$, and $40 \mathrm{ng} / \mathrm{ml} \mathrm{IGF-1.} \mathrm{Cells} \mathrm{were} \mathrm{incubated} \mathrm{at} 37^{\circ} \mathrm{C}$ with $5 \% \mathrm{CO}_{2}$ for another $72 \mathrm{~h}$, and the percentages of surviving cells from each group relative to controls, defined as $100 \%$ survival, were determined by reduction of MTS. Data reflect the means of at least three independent experiments.

at a concentration of $2.5 \mathrm{ng} / \mathrm{ml}$. Next, we performed a timecourse analysis to further verify these results. HRG stimulated both Akt and MAPK in 85815 and 85819 cells, whereas it had no effect on Akt or MAPK activation in the 78423 cells (Fig. $5 b)$. These data were consistent with the results of minimal stimulation by HRG in this cell line (Fig. 4b). In aggregate, these data suggest that HRG induces activation of both MEK/ MAPK and PI-3K/Akt signaling transduction pathways in mammary tumor cells with elevated expression levels of both the transgene rat c-neu/ErbB2 and the endogenous mouse 
Figure 5

(a)

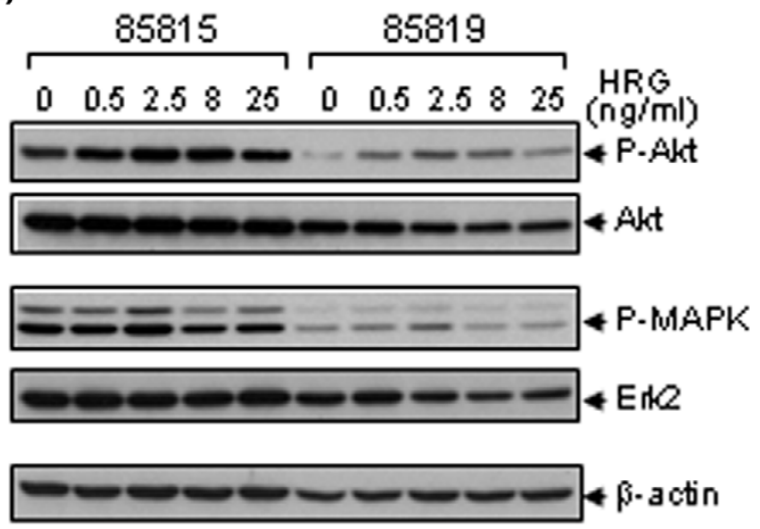

(b)

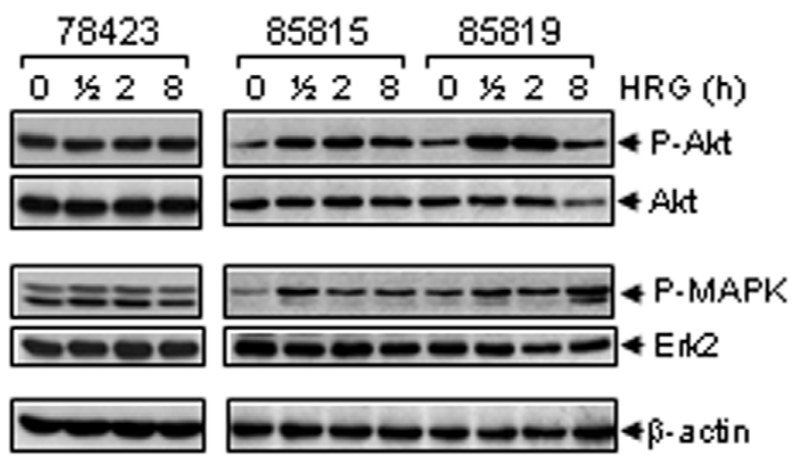

Effects of HRG on the phosphorylation of Akt and MAPK in tumorderived cells. (a) 85815 and 85819 cells were cultured overnight in medium containing $0.5 \%$ FBS before being exposed to HRG at the indicated concentrations for $2 \mathrm{~h}$. Cells were harvested and $50 \mu \mathrm{g}$ total cell lysates were subjected to Western blot analysis for total Akt, phosphorylated Akt, total ERK2 (polyclonal antibody C-14; Santa Cruz Biotechnology, Inc, Santa Cruz, CA, USA), and phosphorylated MAPK (E10 mAb; Cell Signaling Technology) expression. $\beta$-actin was used as loading control. (b) 78423,85815 and 85819 cells were cultured overnight in medium containing $0.5 \%$ FBS before being exposed to 2.5 $\mathrm{ng} / \mathrm{ml} \mathrm{HRG}$ for the indicated time intervals. At each time point, cells were harvested and $50 \mu \mathrm{g}$ total cell lysates were subjected to Western blot analysis for total Akt, phosphorylated Akt, total ERK2, and phosphorylated MAPK expression. $\beta$-actin was used as loading control.

ErbB3 gene. This activation was both dose- and time-dependent.

To study cross-species functional interactions between the rat c-neu/ErbB2 transgene and mouse ErbB3, we evaluated tumor and tissue expression in vivo, ligand-associated interactions, and signaling in vitro. Immunohistochemical studies showed cytoplasmic P-Akt and P-MAPK expression in tumor cells with erbB2 and erbB3 co-expression,
Figure 6

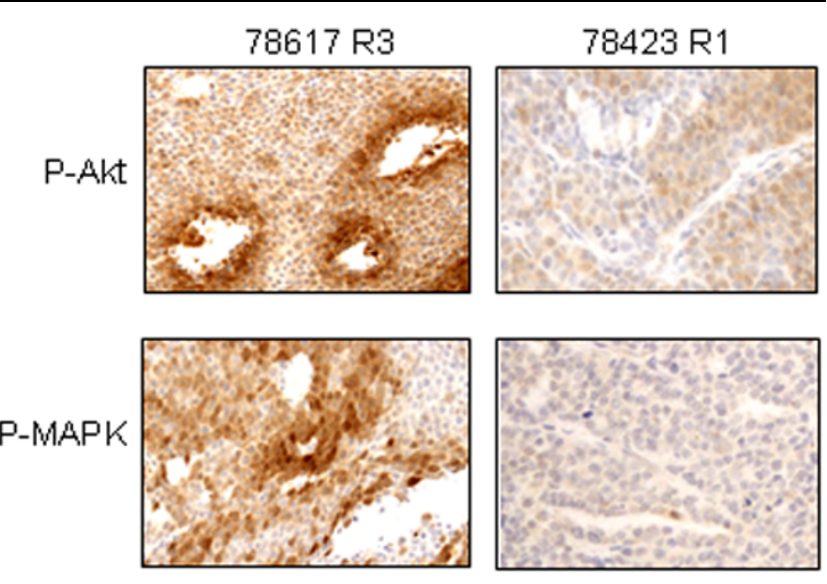

Immunohistochemical staining for phospho-Akt (P-Akt) and phosphoMAPK (P-MAPK) in 78617 R3 and $78423 \mathrm{R} 1$ mammary tumor tissues. Procedure used was similar to Fig. 2. Representative photomicrographs were taken from perivascular areas of the tumor sections (20X).

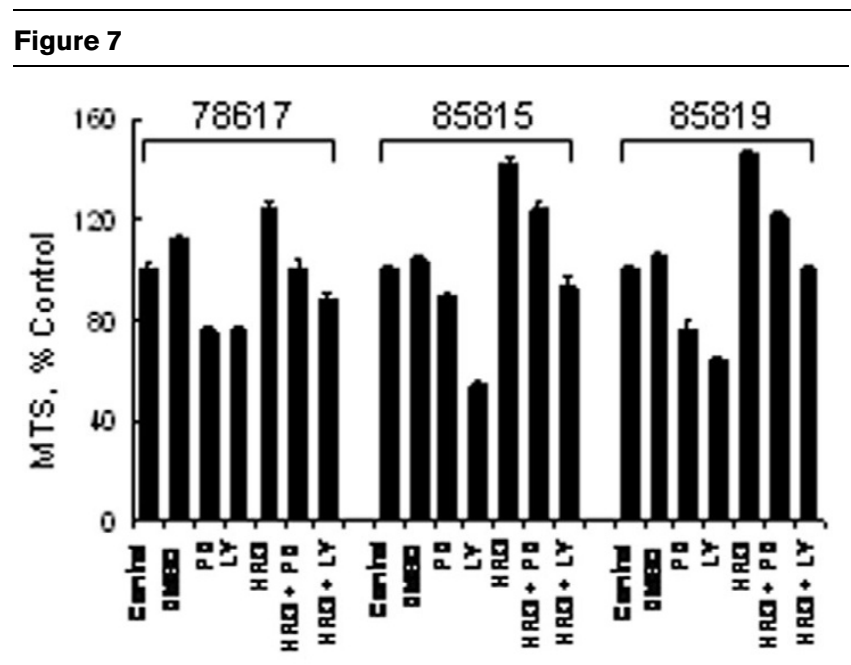

Inhibitory effects of PD98059 and LY294002 blocking HRG-mediated tumor cell proliferation. The indicated breast cancer cells $\left(5 \times 10^{3}\right)$ in $0.1 \mathrm{ml}$ culture media were plated onto 96 -well plates. After $24 \mathrm{~h}$ incubation, cells were grown in either $0.1 \mathrm{ml}$ fresh medium with $0.5 \%$ FBS as control, or $0.1 \mathrm{ml}$ same medium containing PD98059 (6.7 $\mu \mathrm{M}$ for 78617 and $85815,5 \mu \mathrm{M}$ for 85819 ), or LY294002 (3.3 $\mu \mathrm{M}$ for 78617 and $85815,2.5 \mu \mathrm{M}$ for 85819 ), or $25 \mathrm{ng} / \mathrm{ml} \mathrm{HRG}$ alone or in combination of the same concentrations of HRG and PD98059, or HRG and LY294002. Cells were incubated at $37^{\circ} \mathrm{C}$ with $5 \% \mathrm{CO}_{2}$ for another 72 $\mathrm{h}$, and the percentages of surviving cells from each group relative to controls, defined as $100 \%$ survival, were determined by reduction of MTS. Data reflect the means of at least three independent experiments.

predominantly a perivascular distribution. In rare tumors without erbB2 and erbB3 expression (e.g. 78423 R1), the perivascular distribution was not identified and only rare cells showed immunoreactivity. This evidence of perivascular pathway activation suggests that ligand-associated signaling via erbB3 may be involved. Ligand-associated signaling probably pro- 
Figure 8

(a)

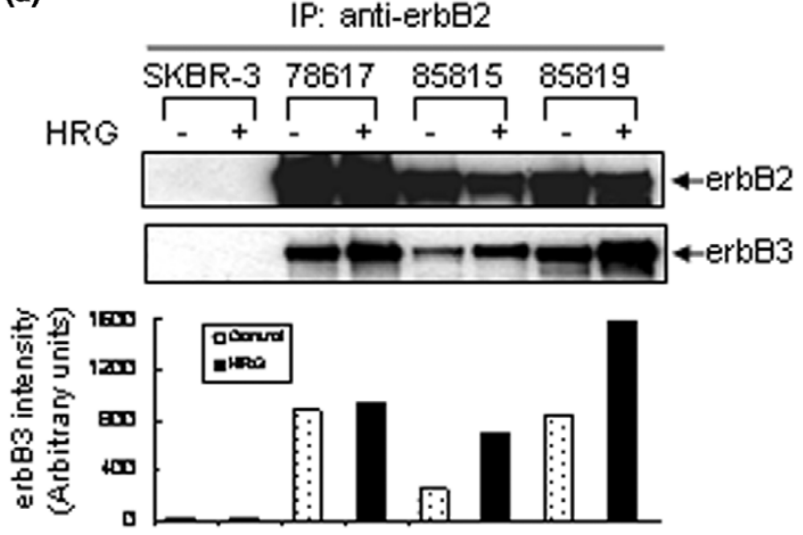

(b)

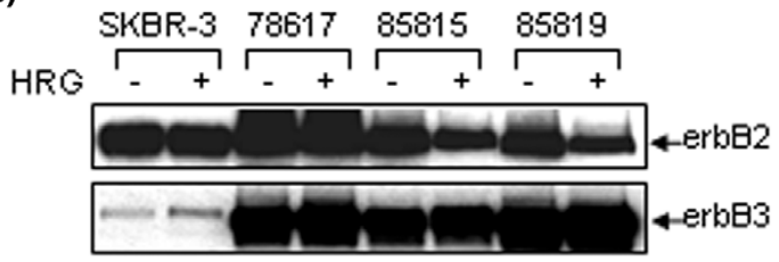

Increased physical associations between wt-rat c-neu protein and mouse erbB3 by HRG treatment. (a) The indicated breast cancer cells were cultured overnight in medium containing $0.5 \% \mathrm{FBS}$, and then incubated with or without $2.5 \mathrm{ng} / \mathrm{ml} \mathrm{HRG}$ for another $2 \mathrm{~h}$. Cell lysates were prepared and $200 \mu \mathrm{g}$ of total protein was subjected to immunoprecipitation with anti-erbB2 specific antibody (c-neu Ab-4), followed by Western blot analysis for erbB2 (c-neu Ab-3) and erbB3. The bar graph underneath was obtained by densitometry analysis. The relative signal intensities of erbB3 were measured by EAGLE EYE ${ }^{\mathrm{TM}}$ II (Stratagene, La Jolla, CA, USA). (b) The same bath of $50 \mu \mathrm{g}$ total cell lysates was subjected to Western blot analysis with antibodies directed against erbB2 and erbB3.

vides enhanced growth or pro-tumorigenic signaling, in addition to ligand-independent, transgene activation. Our data, and those from others showing frequent erbB3 upregulation in transgenic mice bearing activated neu/ErbB2, suggest that the concomitant upregulation of erbB3 and ligand-associated signaling may be an important additional factor in both wt and activated neu/ErbB2-associated mammary tumor development. To further define the role of HRG (ligand)-associated signaling, we utilized derived cell lines and specific inhibitors in vitro. The PI-3K inhibitor LY294002 was significantly more potent than the MEK inhibitor PD98059 in blocking the stimulatory effects of HRG (Fig. 7). Hence, while the MEK/MAPK and PI-3K/Akt signaling cascades both contribute HRG induced proliferation, the PI-3K/Akt pathway appears to provide the dominant response.

\section{Physical interaction between wt-rat-c-neu/ErbB2 and endogenous mouse erbB3}

The erbB2/erbB3 complex is believed to be the most biologically active erbB heterodimer $[43,44]$, with potent activation of the downstream signaling cascade [13,14]. Since both erbB2 and erbB3 were highly expressed by our mammary tumor cell lines and HRG-promoted tumor cell proliferation, we sought physical evidence that the wt-rat-neu/ErbB2 could form a complex with the endogenous mouse erbB3. Immunoprecipitation of erbB2, followed by Western blot analysis for erbB2 and erbB3 (Fig. 8a) showed a low level of complex formation between these receptors in untreated cell lines. HRG treatment significantly increased the physical interaction between the rat transgene and mouse erbB3 in two out of three cell lines. The antibody we used for immunoprecipitation (c-neu Ab-4) appeared to be wt-rat-neu/ErbB2-specific, because human erbB2 was not immunoprecipitated from SKBR-3 cell lysates (Fig. 8a, upper panel), although it was expressed by SKBR-3 cells (Fig. 8b, Western blot analysis with c-neu Ab-3). HRG treatment (for $2 \mathrm{~h}$ ) did not increase the total protein levels of erbB2 or erbB3 as compared with untreated cell lines (Fig. 8b).

\section{Discussion}

We have shown that transgenic mice bearing the wt-rat c-neu gene, under control of the MMTV promoter, develop mammary tumors that overexpress the rat c-neu transgene $[45,46]$ and the endogenous mouse erbB3 protein, in the vast majority of cases. We have shown a functional interaction between these two important RTK receptors and a role for ligand-induced signaling in vitro and in vivo. While others have reported that transgenic mice bearing activated forms of rat c-neulerbB2 have co-expression of erbB2 and endogenous erbB3 in mammary tumors [32], direct physical and functional interactions between these two species receptors have not previously been reported.

Deletion mutants of the neu oncogene have been reported in two out of three of the mammary tumors derived from this wtrat c-neu transgenic model [38]. We did not find the same mutation rate or type in selected tumor-derived cell lines. However, we have identified a potential point mutation in 83923 cells (Fig. 3). This missense mutation is located inside the same extracellular region of neu where the deletion mutations have been reported. This particular mutation changes the amino acid 654 serine (codon AGC) into cysteine (codon TGC). It is different from the active neu mutation G664V reported in the transmembrane domain [47]. The biological significance of the newly discovered S654C mutant neu is not yet known.

Using ligand stimulation with or without specific inhibitors, we have studied RTK-induced signaling in response to $H R G$ and have shown activation of both PI-3K/Akt and the MEK/MAPK signal transduction pathways. A greater role for PI-3K/Akt 
signaling was suggested in response to HRG treatment (Fig. 7). PI-3K/Akt signaling is known to be regulated by erbB2mediated tyrosine kinase activity. This pathway plays a crucial role in cell proliferation and survival [18] and has been associated with the pathogenesis of human breast cancers. PI-3K/ Akt activation has also been cited as a key pathway that influences chemo-resistance patterns [48,49]. Akt is frequently upregulated in ErbB2 amplified or overexpressing human breast cancer cells. These similarities between our transgenic model and human breast carcinogenesis suggest that the model and derived tumor cell lines may be a useful resource to study ligand dependent and independent RTK signaling in vivo and in vitro.

As a major ligand for erbB3, HRG is known to bind to erbB3, foster heterodimer complex formation and promote potent downstream signaling [12]. HRG can thus promote mammary tumorigenesis, cell growth, differentiation and phenotypic aggression [50]. Our immunohistochemical studies of tumors for phosphorylated proteins facilitated studies of the cellular location and architectural context of signaling. We noted enhanced phosphorylated Akt and MAPK in a perivascular distribution in mammary tumors, with overexpression of both erbB2 and erbB3 (Fig. 6), suggesting that circulating HRG may enhance the physical and functional erbB2/erbB3 interactions in vivo, similar to what we observe in vitro. This study has focused primarily on erbB3, whereas others have demonstrated upregulation of EGFR in tumors (by immunohistochemistry and Western blot) in the same model system [33]. Low and variable expression of EGFR has also been found in mammary tumors that develop in transgenic mice bearing activated forms of rat c-neu/ErbB2 [32]. Using in vitro analyses of the tumor-derived cell lines, we have found no significant physical or functional interaction between EGFR (erbB1) and erbB2 in the presence of EGF (data not shown). However, by immunohistochemical study, we also detected erbB1 expression at the tumor periphery as reported by DiGiovanna [33]. These data suggest to us that erbB3 plays a more significant role in tumorigenesis than erbB1 in this model system.

These data and this model probably have relevance to human breast cancer biology and treatment strategies. We have reported that only a minority of erbB2-altered invasive human breast cancers have overexpression of erbB1 (EGFR) and activation of erbB2 [51]. Given the complexity of the RTK receptors, various ligands and downstream signaling, it is likely that combinations of these factors including erbB3 contribute to cell signaling, biological behavior and treatment response $[52,53]$. To date, the role of erbB3 in human breast carcinogenesis is not well defined, although many investigators have suggested that HRG-associated signaling may be important. In view of these complexities, it is not surprising that erbB2 aberrant breast cancers have shown variable responses to anti-erbB2 therapeutics $[52,53]$. It is widely believed that coexpression of other erbB RTK family members may be one mechanism of Herceptin resistance [54]. Ligand-induced heterodimerization between erbB3 and erbB2, the most potent signaling complex amongst the various heterodimers, is one likely mechanism of Herceptin resistance [55]. More detailed investigations using banks of human tumors and clinical trialassociated specimens, to define the incidence of erbB3 abnormalities, functional complex formation and downstream signaling, may provide important new clues regarding these interactions and their role in breast carcinogenesis.

\section{Conclusion}

Our results indicate that over-expression of endogenous mouse erbB3 plays an important role in the development and progression of mammary tumors that arise in mice bearing the wt-rat c-neu transgene. The functional and physical interactions between these important cross-species erbB receptors result in activation of both $\mathrm{PI}-3 \mathrm{~K} / \mathrm{Akt}$ and MEK/MAPK signaling. These data support the concept that ligand-dependent and -independent signaling through erbB2 may promote mammary tumorigenesis in these transgenic mice, similar to what is observed in human breast cancers.

\section{Competing interests}

The author(s) declare that they have no competing interests.

\section{Authors' contributions}

The authors' contributions to this research work are reflected in the order shown, with the exception of ADT who supervised the research and finalized the report. AK, BL and DOE carried out most of the experiments. $A K$ and $B L$ drafted the manuscript. KMA collected mammary tumors from the transgenic mice. LDJ performed immunohistochemistry analysis. CM maintained tumor cell culture. SME, $X Y$ and ADT conceived the study and participated in its design and coordination. All authors read and approved the final manuscript.

\section{Acknowledgements}

This work was supported by NIH 1RO1 CA82848 and 1P50 CA89018 to ADT.

\section{References}

1. Olayioye MA, Neve RM, Lane HA, Hynes NE: The ErbB signaling network: receptor heterodimerization in development and cancer. EMBO J 2000, 19:3159-3167.

2. deFazio A, Chiew YE, Sini RL, Janes PW, Sutherland RL: Expression of c-erbB receptors, heregulin and oestrogen receptor in human breast cell lines. Int J Cancer 2000, 87:487-498.

3. Coussens L, Yang-Feng TL, Liao YC, Chen E, Gray A, McGrath J, Seeburg PH, Libermann TA, Schlessinger J, Francke U, et al.: Tyrosine kinase receptor with extensive homology to EGF receptor shares chromosomal location with neu oncogene. Science 1985, 230:1132-1139.

4. King CR, Kraus MH, Aaronson SA: Amplification of a novel verbB-related gene in a human mammary carcinoma. Science 1985, 229:974-976.

5. Plowman GD, Culouscou JM, Whitney GS, Green JM, Carlton GW, Foy L, Neubauer MG, Shoyab M: Ligand-specific activation of HER4/p180erbB4, a fourth member of the epidermal growth factor receptor family. Proc Natl Acad Sci USA 1993, 90:1746-1750. 
6. Kraus MH, Issing W, Miki T, Popescu NC, Aaronson SA: Isolation and characterization of ERBB3, a third member of the ERBB/ epidermal growth factor receptor family: evidence for overexpression in a subset of human mammary tumors. Proc Natl Acad Sci USA 1989, 86:9193-9197.

7. Plowman GD, Whitney GS, Neubauer MG, Green JM, McDonald VL, Todaro GJ, Shoyab M: Molecular cloning and expression of an additional epidermal growth factor receptor-related gene. Proc Natl Acad Sci USA 1990, 87:4905-4909.

8. Riese DJ 2nd, Stern DF: Specificity within the EGF family/ErbB receptor family signaling network. Bioessays 1998, 20:41-48.

9. Graus-Porta D, Beerli RR, Daly JM, Hynes NE: ErbB-2, the preferred heterodimerization partner of all ErbB receptors, is a mediator of lateral signaling. EMBO $J 1997,16: 1647-1655$.

10. Penuel $E$, Akita RW, Sliwkowski MX: Identification of a region within the ErbB2/HER2 intracellular domain that is necessary for ligand-independent association. I Biol Chem 2002, 277:28468-28473.

11. Holbro T, Beerli RR, Maurer F, Koziczak M, Barbas CF 3rd, Hynes $\mathrm{NE}$ : The ErbB2/ErbB3 heterodimer functions as an oncogenic unit: ErbB2 requires ErbB3 to drive breast tumor cell proliferation. Proc Natl Acad Sci USA 2003, 100:8933-8938.

12. Tzahar $E$, Waterman $H$, Chen $X$, Levkowitz G, Karunagaran $D$, Lavi S, Ratzkin BJ, Yarden Y: A hierarchical network of interreceptor interactions determines signal transduction by Neu differentiation factor/neuregulin and epidermal growth factor. Mol Cell Biol 1996, 16:5276-5287.

13. Harari $D$, Yarden $Y$ : Molecular mechanisms underlying ErbB2/ HER2 action in breast cancer. Oncogene 2000, 19:6102-6114.

14. Yarden $Y$, Sliwkowski MX: Untangling the ErbB signalling network. Nat Rev Mol Cell Biol 2001, 2:127-137.

15. Alimandi M, Romano A, Curia MC, Muraro R, Fedi $P$, Aaronson SA, Di Fiore PP, Kraus MH: Cooperative signaling of ErbB3 and ErbB2 in neoplastic transformation and human mammary carcinomas. Oncogene 1995, 10:1813-1821.

16. Wallasch C, Weiss FU, Niederfellner G, Jallal B, Issing W, Ullrich A: Heregulin-dependent regulation of $\mathrm{HER} 2 /$ neu oncogenic signaling by heterodimerization with HER3. EMBO J 1995, 14:4267-4275.

17. Chang HW, Aoki M, Fruman D, Auger KR, Bellacosa A, Tsichlis PN, Cantley LC, Roberts TM, Vogt PK: Transformation of chicken cells by the gene encoding the catalytic subunit of PI 3-kinase. Science 1997, 276:1848-1850.

18. Hermanto $\mathrm{U}$, Zong CS, Wang LH: ErbB2-overexpressing human mammary carcinoma cells display an increased requirement for the phosphatidylinositol 3-kinase signaling pathway in anchorage-independent growth. Oncogene 2001, 20:7551-7562.

19. Pearson G, Robinson F, Beers Gibson T, Xu BE, Karandikar M, Berman K, Cobb MH: Mitogen-activated protein (MAP) kinase pathways: regulation and physiological functions. Endocr Rev 2001, 22:153-183.

20. Slamon DJ, Clark GM, Wong SG, Levin WJ, Ullrich A, McGuire WL: Human breast cancer: correlation of relapse and survival with amplification of the HER-2/neu oncogene. Science 1987, 235:177-182.

21. Slamon DJ, Godolphin W, Jones LA, Holt JA, Wong SG, Keith DE, Levin WJ, Stuart SG, Udove J, Ullrich A, et al:: Studies of the HER-2/neu proto-oncogene in human breast and ovarian cancer. Science 1989, 244:707-712.

22. Paterson MC, Dietrich KD, Danyluk J, Paterson AH, Lees AW, Jamil N, Hanson J, Jenkins H, Krause BE, McBlain WA, et al.: Correlation between c-erbB-2 amplification and risk of recurrent disease in node-negative breast cancer. Cancer Res 1991, 51:556-567.

23. Gullick WJ, Love SB, Wright C, Barnes DM, Gusterson B, Harris AL, Altman DG: c-erbB-2 protein overexpression in breast cancer is a risk factor in patients with involved and uninvolved lymph nodes. Br J Cancer 1991, 63:434-438.

24. Andrulis IL, Bull SB, Blackstein ME, Sutherland D, Mak C, Sidlofsky S, Pritzker KP, Hartwick RW, Hanna W, Lickley L, et al.: neu/ erbB-2 amplification identifies a poor-prognosis group of women with node-negative breast cancer. Toronto Breast Cancer Study Group. J Clin Oncol 1998, 16:1340-1349.

25. Thor AD, Liu S, Edgerton S, Moore D 2nd, Kasowitz KM, Benz CC, Stern DF DiGiovanna MP: Activation (tyrosine phosphorylation) of ErbB-2 (HER-2/neu): a study of incidence and correlation with outcome in breast cancer. J Clin Oncol 2000, 18:3230-3239.

26. Bieche I, Onody P, Tozlu S, Driouch K, Vidaud M, Lidereau R: Prognostic value of ERBB family mRNA expression in breast carcinomas. Int J Cancer 2003, 106:758-765.

27. Chow NH, Chan SH, Tzai TS, Ho CL, Liu HS: Expression profiles of ErbB family receptors and prognosis in primary transitional cell carcinoma of the urinary bladder. Clin Cancer Res 2001, 7:1957-1962.

28. Bouchard L, Lamarre L, Tremblay PJ, Jolicoeur P: Stochastic appearance of mammary tumors in transgenic mice carrying the MMTV/c-neu oncogene. Cell 1989, 57:931-936.

29. Guy CT, Webster MA, Schaller M, Parsons TJ, Cardiff RD, Muller WJ: Expression of the neu protooncogene in the mammary epithelium of transgenic mice induces metastatic disease. Proc Natl Acad Sci USA 1992, 89:10578-10582.

30. Muller WJ, Sinn E, Pattengale PK, Wallace R, Leder P: Singlestep induction of mammary adenocarcinoma in transgenic mice bearing the activated c-neu oncogene. Cell 1988, 54:105-115.

31. Andrechek ER, Hardy WR, Siegel PM, Rudnicki MA, Cardiff RD, Muller WJ: Amplification of the neu/erbB-2 oncogene in a mouse model of mammary tumorigenesis. Proc Natl Acad Sci USA 2000, 97:3444-3449.

32. Siegel PM, Ryan ED, Cardiff RD, Muller WJ: Elevated expression of activated forms of Neu/ErbB-2 and ErbB-3 are involved in the induction of mammary tumors in transgenic mice: implications for human breast cancer. EMBO J 1999, 18:2149-2164.

33. DiGiovanna MP, Lerman MA, Coffey RJ, Muller WJ, Cardiff RD, Stern DF: Active signaling by Neu in transgenic mice. Oncogene 1998, 17:1877-1884.

34. Li B, Rosen JM, McMenamin-Balano J, Muller WJ, Perkins AS: neu/ERBB2 cooperates with $\mathrm{p53}-172 \mathrm{H}$ during mammary tumorigenesis in transgenic mice. Mol Cell Biol 1997 17:3155-3163.

35. Jeruss JS, Liu NX, Chung Y, Magrane G, Waldman F, Edgerton S, Yang $X$, Thor AD: Characterization and chromosomal instability of novel derived cell lines from a wt-erbB-2 transgenic mouse model. Carcinogenesis 2003, 24:659-664.

36. Yang X, Edgerton SM, Kosanke SD, Mason TL, Alvarez KM, Liu N Chatterton RT, Liu B, Wang Q, Kim A, et al.: Hormonal and dietary modulation of mammary carcinogenesis in mouse mammary tumor virus-c-erbB-2 transgenic mice. Cancer Res 2003, 63:2425-2433.

37. Liu B, Edgerton SM, Yang X, Kim A, Ordonez-Ercan D, Mason TL, Alvarez KM, McKimmey C, Liu N, Thor AD: Low dose dietary phytoestrogen abrogates tamoxifen associated mammary tumor prevention. Cancer Res 2005, 65:879-886.

38. Siegel P, Dankort D, Hardy W, Muller W: Novel activating mutations in the neu proto-oncogene involved in induction of mammary tumors. Mol Cell Biol 1994, 14:7068-7077.

39. Thor AD, Berry DA, Budman DR, Muss HB, Kute T, Henderson IC, Barcos M, Cirrincione C, Edgerton S, Allred C, et al.: erbB-2, p53, and efficacy of adjuvant therapy in lymph node-positive breast cancer [comment]. J Natl Cancer Inst 1998, 90:1346-1360.

40. Liu B, Fang M, Lu Y, Mendelsohn J, Fan Z: Fibroblast growth factor and insulin-like growth factor differentially modulate the apoptosis and G1 arrest induced by anti-epidermal growth factor receptor monoclonal antibody. Oncogene 2001, 20:1913-1922.

41. Anzick SL, Kononen J, Walker RL, Azorsa DO, Tanner MM, Guan XY, Sauter G, Kallioniemi OP, Trent JM, Meltzer PS: AIB1, a steroid receptor coactivator amplified in breast and ovarian cancer. Science 1997, 277:965-968.

42. Kosanke S, Edgerton SM, Moore D 2nd, Yang X, Mason T, Alvarez $\mathrm{K}$, Jones L, Kim A, Thor AD: Mammary tumor heterogeneity in wt-ErbB-2 transgenic mice. Comp Med 2004, 54:280-287.

43. Riese DJ 2nd, van Raaij TM, Plowman GD, Andrews GC, Stern DF: The cellular response to neuregulins is governed by complex interactions of the erbB receptor family. Mol Cell Biol 1995 15:5770-5776. [Erratum Mol Cell Biol 1996, 16:735]

44. Pinkas-Kramarski R, Soussan L, Waterman H, Levkowitz G, Alroy I, Klapper L, Lavi S, Seger R, Ratzkin BJ, Sela M, Yarden Y: Diversification of Neu differentiation factor and epidermal growth factor signaling by combinatorial receptor interactions. $E M B O$ J 1996, 15:2452-2467. 
45. Sacco MG, Gribaldo L, Barbieri O, Turchi G, Zucchi I, Collotta A, Bagnasco L, Barone D, Montagna C, Villa A, et al:: Establishment and characterization of a new mammary adenocarcinoma cell line derived from MMTV neu transgenic mice. Breast Cancer Res Treat 1998, 47:171-180.

46. Campbell MJ, Wollish WS, Lobo M, Esserman LJ: Epithelial and fibroblast cell lines derived from a spontaneous mammary carcinoma in a MMTV/neu transgenic mouse. In Vitro Cell Dev Biol Anim 2002, 38:326-333.

47. Bargmann $\mathrm{Cl}$, Hung $\mathrm{MC}$, Weinberg RA: Multiple independent activations of the neu oncogene by a point mutation altering the transmembrane domain of p185. Cell 1986, 45:649-657.

48. Bacus SS, Altomare DA, Lyass L, Chin DM, Farrell MP, Gurova K, Gudkov A, Testa JR: AKT2 is frequently upregulated in HER-2/ neu-positive breast cancers and may contribute to tumor aggressiveness by enhancing cell survival. Oncogene 2002, 21:3532-3540.

49. Knuefermann C, Lu Y, Liu B, Jin W, Liang K, Wu L, Schmidt M, Mills GB, Mendelsohn J, Fan Z: HER2/PI-3K/Akt activation leads to a multidrug resistance in human breast adenocarcinoma cells. Oncogene 2003, 22:3205-3212.

50. Lupu R, Cardillo M, Cho C, Harris L, Hijazi M, Perez C, Rosenberg $\mathrm{K}$, Yang $\mathrm{D}$, Tang C: The significance of heregulin in breast cancer tumor progression and drug resistance. Breast Cancer Res Treat 1996, 38:57-66.

51. DiGiovanna MP, Stern DF, Edgerton S, Whalen SG, Moore D 2nd, Thor AD: Relationship of epidermal growth factor receptor expression to ErbB2-signaling activity and prognosis in breast cancer patients. J Clin Oncol 2005, 23:1152-1160.

52. Baselga J, Tripathy D, Mendelsohn J, Baughman S, Benz CC, Dantis L, Sklarin NT, Seidman AD, Hudis CA, Moore J, et al:: Phase II study of weekly intravenous recombinant humanized antip185HER2 monoclonal antibody in patients with HER2/neuoverexpressing metastatic breast cancer [comment]. J Clin Oncol 1996, 14:737-744.

53. Cobleigh MA, Vogel CL, Tripathy D, Robert NJ, Scholl S, Fehrenbacher L, Wolter JM, Paton V, Shak S, Lieberman G, Slamon DJ: Multinational study of the efficacy and safety of humanized anti-HER2 monoclonal antibody in women who have HER2overexpressing metastatic breast cancer that has progressed after chemotherapy for metastatic disease. J Clin Oncol 1999, 17:2639-2648.

54. Cardoso F, Piccart MJ, Durbecq V, Di Leo A: Resistance to trastuzumab: a necessary evil or a temporary challenge? Clin Breast Cancer 2002, 3:247-257.

55. Agus DB, Akita RW, Fox WD, Lewis GD, Higgins B, Pisacane PI, Lofgren JA, Tindell C, Evans DP, Maiese $K$, et al.: Targeting ligand-activated ErbB2 signaling inhibits breast and prostate tumor growth [comment]. Cancer Cell 2002, 2:127-137. 